\title{
ХАРАКТЕРИСТИКА КОЛИЧЕСТВЕННОГО СОСТАВА МИКОБИОТЫ ОТХОДОВ НЕПРОДОВОЛЬСТВЕННЫХ ТОВАРОВ РАСТИТЕЛЬНОГО ПРОИСХОЖДЕНИЯ
}

\section{CHARACTERISTICS OF QUALITY COMPOSITION OF MYKOBIOTA DISPOSAL OF NON-PRODUCTIVE PRODUCTS GROW PRODUCTION}

\section{U. Nematova}

Summary. During the study of the assessment of the quantitative composition of mycobiotics of plant materials used in non-food purposes. It is found that the quantitative composition of mycobiotics in the products under study has indicators of a specific nature, and over time, the moisture and chemical composition of materials are factors that affect its formation.

Keywords: plant, non-food product, mycobiota, quantitative composition, chemical composition, moisture.

\author{
Нематова Улькер Вагиф \\ Диссертант, Институт Микробиологии НАНА, \\ 2. Баку \\ azmbi@mail.ru
}

Аннотация. В ходе исследования дана оценка количественного состава микобиоты растительных материалов, используемых в непищевых целях. Выявлено, что количественный состав микобиоты исследуемых продуктов обладает показателями специфического характера, а времена года, влажность и химический состав материалов являются факторами, существенно влияющих на её формирование.

Ключевые слова: растения, непродовольственный товар, микобиота, количественный состав, химический состав, влажность.

дукты, изготовление которых также приводит к образованию отходов различного объёма и состава [16]. Эти отходы в большинстве случаев не имеют показателей, позволяющих перерабатывать их в том виде, в котором они созданы, и их неконтролируемые выбросы становятся одним из источников загрязнения окружающей среды. Наибольшее количество этих отходов образуется при обработке древесины, встречаются в производствах строительных материалов, мебели и т.д. Присутствие в этих отходах различных, имеющих определенную значимость химических компонентов приводит к необходимости рассмотрения их как потенциальных источников сырья. С другой стороны, эти отходы содержат также благоприятные для микроорганизмов питательные вещества, но в то же время они являются одним из источников обитания и распространения микроорганизмов, а также способствуют биологическому загрязнению окружающей среды. Таким образом, утилизация такого рода отходов, то есть их обезвреживание или превращение в полезные с точки зрения практических нужд продукты, является сегодня актуальной проблемой.

Известно, что для решения любой проблемы важно четко определить ее "участников», и в данном случае основным участником, требующим уточнения, явля- 
Таблица 1. Сезонное изменение количественного состава микобиоты анализируемых материалов $\left(\mathrm{x} 10^{3} \mathrm{KOE} / \mathrm{r}\right)$

\begin{tabular}{|l|l|l|l|l|}
\hline Анализируемые материалы & 3има & Весна & Лето & Осень \\
\hline Древесные щепки (широколиственные) & 1,72 & 2,82 & 3,17 & 3,15 \\
\hline Древесные щепки (хвойные) & 0,31 & 0,53 & 0,71 & 0,70 \\
\hline Древесные щепки (смешанные) & 0,93 & 1,43 & 1,54 & 1,49 \\
\hline Упаковочая материал (картон) & 0,43 & 0,74 & 0,94 & 0,90 \\
\hline Упаковочный материал (бумага) & 0,39 & 0,64 & 0,76 & 0,73 \\
\hline
\end{tabular}

ется микробиота материалов растительного сырья, независящее от цели использования, и первый шаг в исследовании этого вопроса заключается в том, чтобы оценить количественный и качественный состав, а затем изучить другие особенности (физиологические, биохимические, экологические, биотехнологические, токсикологические и т.д.) микобиоты.

Поэтому целью данной работы является характеристика микробиоты непищевых отходов растений, используемых в Азербайджане для технических, а также для пищевых целей, и определение факторов, влияющих на её формирование.

Следует отметить, что под микробиотой подразумевается совокупность бактерий и микроскопических грибов, обитающих в определенном материале. Бактерии и грибы характеризуются разнообразием как по количеству, так и по видовому составу и различаются методами и подходами, используемыми для характеристики их разнообразия в перечисленных выше аспектах. По этой причине в настоящем исследовании для характеристики микробиоты в первую очередь использовались грибы. Характеристика грибов в данной работе представлена только количественным составом. Это связано с тем, что в санитарно-гигиенических и эпидемиологических документах на пищевые продукты допустимые показатели грибов определяются по их количеству, а в некоторых случаях - по количеству общих групп (например, дрожжи, плесневые грибы и т.д.).

\section{Материалы и метолы}

В качестве образцов для исследования использовались материалы (древесные щепки) предприятий, производящих различные деревянные изделия, а также одноразовые материалы для упаковки пищевых продуктов.

Отбор проб, подготовка их к посеву, посев на питательную среду, выращивание, выделение в чистую культуру проводилось в соответствии с методами и подходами, принятыми в микробиологии и микологии $[1,7]$.
Пробы отбирались по сезонам, точнее в первой декаде первого месяца каждого квартала.

Для характеристики количественного состава микроорганизмов (колониеобразующая единица-КОЕ) была использована следующая формула:

$$
\mathrm{N}=\mathrm{abc} / \mathrm{d}
$$

Здесь N - количество грибов (KOЕ/ г сухого материала), а - количество колоний, образовавшихся в чашке Петри, b - количество разведения, количество капель в 1 мл суспензии, d - вес взятого на анализ материала (в г.).

Идентификацию грибов проводили по определителям, составленным на основе культурально-морфологических и физиологических признаков $[8,17]$.

Определение химического состава, а также влажности отходов проводилось в соответствии с общепринятыми принципами.

В ходе исследования все эксперименты проводились в 4-х- 6-ти повторениях, а значения, отвечающие формуле $\mathrm{m} / \mathrm{M}=\mathrm{P} \leq 0,05$ считались достоверными[4].

\section{Полученные результаты \\ и их обсу>}

В ходе анализа отобранных для исследования образцов было выявлено, что микобиота каждого из них в определенной степени характеризуется количественной специфичностью, которая находит свое наибольшее выражение в образцах, взятых с щепок лиственных деревьев, причем показатели каждого материала меняются в зависимости от сезона (таблица 1).

Как видно, показатели, характеризующие количественный состав микобиоты всех материалов, имеют наивысшие значения летом, точнее в июне. У исследованных образцов самые низкие показатели наблюдаются зимой. Причиной этого может служить температурный фактор, так как подавляющее большинство грибов 
Таблица 2. Влияние влажности на изменение количественного состава микобиоты анализируемых материалов

\begin{tabular}{|c|c|c|c|c|}
\hline \multirow{2}{*}{ Анализируемые материалы } & \multicolumn{4}{|c|}{ Влажность,\% } \\
\hline & $<10$ & 15 & 20 & $>20$ \\
\hline $\begin{array}{l}\text { Древесные щепки } \\
\text { (широколиственные) }\end{array}$ & 0,92 & 3,2 & 4,0 & 4,6 \\
\hline Древесные щепки (хвойные) & 0,10 & 0,53 & 0,71 & 0,79 \\
\hline Древесные щепки (смешанные) & 0,37 & 1,48 & 1,74 & 1,92 \\
\hline
\end{tabular}

мезофильны, и оптимальный температурный диапазон для их роста и развития составляет $20-30{ }^{\circ} \mathrm{C}$. Температурный диапазон в Азербайджане в июне находится именно в этом диапазоне.

В отношении результатов по количественному составу грибов стоит отметить еще один момент, который связан с химическим составом отбираемых для исследования отходов. Так, химический состав используемых отходов различаются между собой, что подтверждается как литературными данными $[2,12,14]$, так и некоторыми показателями, выявленными в ходе исследования. Например, основными составляющими щепок как широколиственных, так и хвойных растений являются целлюлоза и лигнин, то есть трудногидролизуемые полисахариды, количество которых в обоих случаях колеблется от 30 до 50\%. Однако микобиота фрагментов, хранящихся в одинаковых условиях и образовавшихся в результате почти одного и того же процесса, существенно различается по количественному составу. Как видно (табл. 1), количество грибов в щепках хвойных деревьев во все сезоны в 4,5-5,5 раза меньше, чем в лиственных деревьях. По сравнению с другими отходами, т.е. используемыми для упаковки, количественный состав микобиоты в щепках хвойных растений характеризуется более низкими показателями. Указанные материалы, то есть картон и бумага, используемые для упаковки, содержат больше целлюлозы.

Как известно, в число метаболитов, образуемых хвойными деревьями, входят фитонциды, а также эти деревья содержат смолистые соединения, которые также обладают антимикробной активностью[9]. Низкое количество грибов в щепках хвойных деревьев связано именно с этими особенностями хвойных.

Влажность - один из важнейших показателей обитания микроорганизмов, особенно грибов, в твердых отходах. Принимая это во внимание, одной из задач исследования явился количественный анализ микобиоты одних и тех же отходов, которые различались по влагосодержанию, а пробы для анализа отбирались из древесных щепок только в одном сезоне (лето). Полученные результаты показали, что количество грибов в зависимости от влажности также меняется, а увеличение влажности выше 10\% сопровождается соответствующим увеличением количества грибов (таблица 2). Как видно, увеличение влажности до 20\% приводит к увеличению количества грибов в щепках широколиственных деревьев в 4,3 раза по сравнению с самым низким здесь показателем (<10). Такое увеличение наблюдается и в результатах с хвойными и смешанными щепками, где оно повысилось соответственно в 7,1 и 4,7 раза. Можно сказать, что влажность также играет важную роль в формировании микобиоты этих отходов.

Таким образом, в результате исследования выявлено, что непищевые отходы также являются одной из сред обитания грибов, а среди факторов, влияющих на существование здесь грибов, определенную роль играют влажность, время года и составные компоненты данных отходов.

\section{ЛИТЕРАТУРА}

1. Мурадов П.З. Изменение активности гидролаз и оксидаз в процессе конверсии растительных отходов. Автореф. дис. доктора биол. наук. Баку, 2004, $48 \mathrm{c}$.

2. Базарнова Н.Г. Химия древесины и ее основных компонентов. Барнаул, 2002, 50 s.

3. Инфекционные болезни: национальное руководство / Под ред. Н.Д. Ящука, Ю.Я. Венгерова. — М.: Гэотармед, 2009.— 1056с.

4. Лакин Г.Ф. Биометрия. М.: Наука, 1990, 352 с.

5. Машанов А.И., Речкина Е.А., Губаненко Г.А. Биологическая безопасность пищевых продуктов. Красноярск: Краснояр. гос. аграрный ун-т, 2016, 117 с.

6. Неклюдов А.Д., Иванкин А.Н. Экологические основы биотехнологии: Учебник. М.: МГУЛ, 2016. — 416 с

7. Нетрусов А.И., Егорова М.А., Захарчук Л.М. и др. Практикум по микробиологии. М.: Издательский центр «Академия», 2005, 一608с.

8. Саттон Д., Фотергилл А., Риналди М. Определитель патогенных и условно патогенных грибов.М.: Мир, 2001, 486с. 
9. Чернышов М.П., Арефьев Ю.Ф., Титов Е.В. и др. Хвойные породы в озеленении Центральной России / Под общей ред. проф. М.П. Чернышова. М.: Колос, 2007, 328 с.

10. Шкурат М.А., Покудина И.О., Батталов Д.В., Резистентность микроорганизмов к атимикробным препаратам // «Живые и биокосные системы», 2014, № 10; URL: http://jbks.ru/archive/issue-10/article-10

11. Balloux F., van Dorp L. What are pathogens, and what have they done to and for us?//BMC Biol, 2017, v.15, p.91

12. Chen S., Zhang X., Singh D. et al. Biological pretreatment of lignocellulosics: potential, progress and challenges.//Biofuels, 2010,1, p.177-199.

13. Dada E.0., Olusola-Makinde 0.0. Microbial and Parasitic Contamination on Vegetables Collected From Retailers in Main Market, Akure, Nigeria.//American J. of Microbiological Research.,-2015, v.3, 3, -p.112-117.

14. Hu F., Ragauskas A. Pretreatment and lignocellulosic chemistry// Bioenergy Research. — 2012, № 5, p.1043-1066.

15. http://www.agroatlas.ru/diseases

16. https://www.eea.europa.eu/signals/signals-2014/articles/waste-a-problem-or-a-resource

17. Kirk P.M.et al. Ainsworti and Bisbys Dictionary of the fungi. 9th edd. CAB International, 2001, $655 \mathrm{p}$.

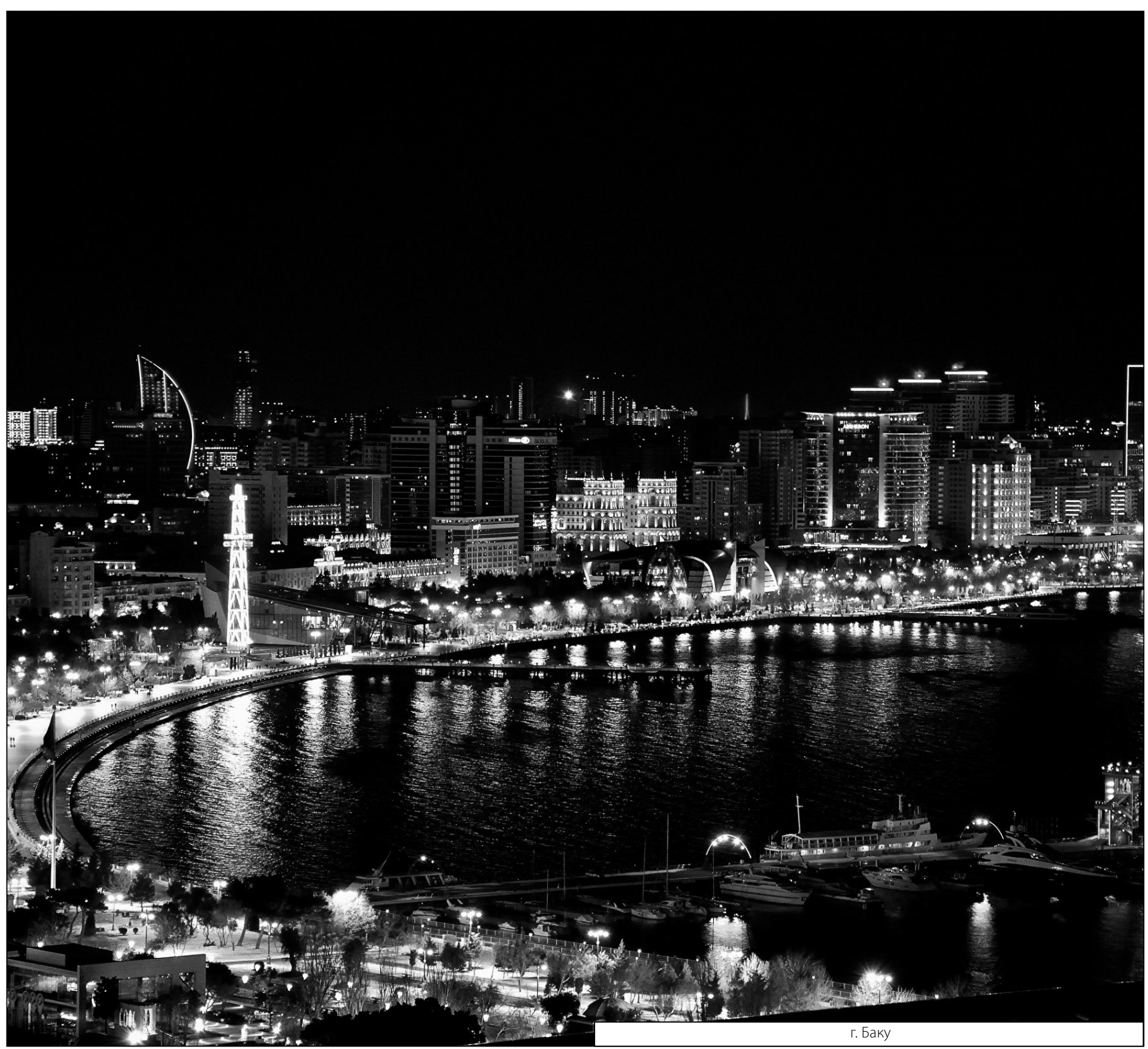

